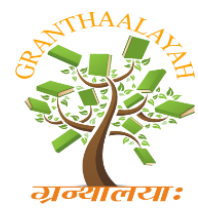

Arts

\section{INTERNATIONAL JOURNAL OF RESEARCH - GRANTHAALAYAH \\ A knowledge Repository}

\title{
WOMEN AS GODDESS IN INDIAN ART
}

\author{
Dr. Anjali Pandey *1 \\ ${ }^{* 1}$ Assistant Professor \& HOD, Department of Drawing \& Painting, Govt. M.L.B. Girls P. G. \\ Autonomous College Bhopal, INDIA
}

\begin{abstract}
In India, we find the worship of great mother in varying forms. The Female figures from Indus civilization indicate the fertility cult. , the early records of terracotta sculpture are the evidences. Since IInd century A.D. Devi Durga, Lakshmi and Matraka are remain popular and worshipped. The goddess on a lion depicted first time in Kushan Period. Some of the goddess is the anthromorphic personification of nature. The Yakshis are the nature goddess. In Folk societies, socialization, education, recreation and communication of new ideas moral values and knowledge are inculcated by the women. They are the active bearer of oral tradition in India.
\end{abstract}

Keywords:

Mother goddess, garbh, hand modelled figures, lakshna, Mahishasur, anthromorphic.

Cite This Article: Dr. Anjali Pandey, "WOMEN AS GODDESS IN INDIAN ART" International Journal of Research - Granthaalayah, Vol. 4, No. 3 (2016): 205-208.

\section{INTRODUCTION}

"Indian at derives its width and hierarchy, and its special nature that steers clear of the contradictions of realism and abstraction. The Indian artist exults in the visual world with knowledge of its variety, impermanence and changeability; he reacts to it in an internal way, looking for its vital constituents, not its immediate facts." 1

"Yatr naryastu pujyante ramante tatr devtah" it has been rightly said and even depicted in Indian culture with the means of art. In Indian art mother goddess is one of the loving subjects for the artist. In ancient India we find the worship of great mother in varying forms. Terracotta was one of the favorite and ageless medium. For popular religious practices and worship terracotta served as the most suitable and convenient material for the artist in expressing their views. "The pot, a symbol of a womb (garbh) represents the Mother goddess in magi co-religious rites and is assimilated into her form as her head and torso in some ancient figurines from northern India ${ }^{2} . "$

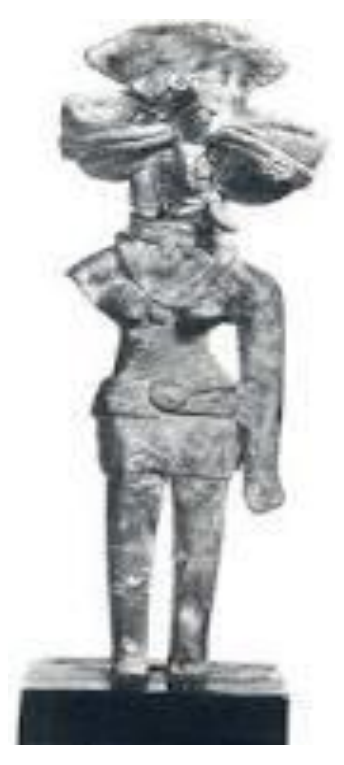




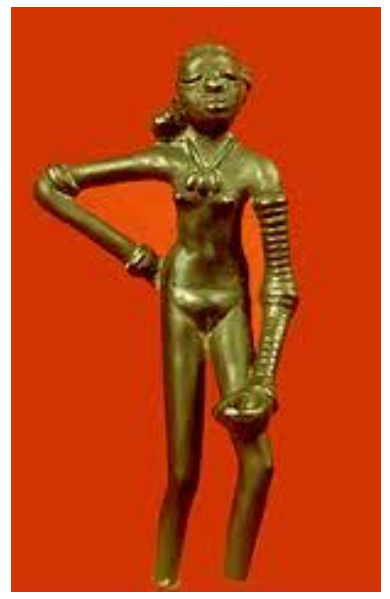

The remote examples of Female figures from Indus civilization (c 23001700) indicate the fertility cult was important part of its religion. The dancing figure of bronze characterized the involvement of women in art. In these figures the artist applied minimum modeling. The hand modelled figures are short and thick. ${ }^{3}$

"The goddess has dual existence, to be worshipped in her own right as an independent deity and as an adjunct to a central male deity, where she is shakti, the essential of female energy that serves as the personification of a god's energy." Since II $^{\text {nd }}$ century A.D. Devi Durga, Lakshmi and Matraka are remain popular. The typical iconography of snake deties could be seen in stylized form .The nude Goddess Lajja Gauri is seated in uttanpad posture are depicted at Andhra Pradesh, Karnataka, Gujrat and Maharashtra. She is also incarnated with the vahan of bull at Bhinmal of Rajasthan and Vadgaon of Maharashtra. Shri Lakshmi is elevated as the goddess of wealth, fortune and prosperity.

Gaj Lakshmi is very common in Hindu and Buddhist Iconography. In the medallion of stone from Bharut 100-80 BCE two elephants are pouring water over the goddess Lakshmi, the figures are standing or seated cross legged on a lotus. On eastern Gatway of Sanchi Goddess is being depicted in seated posture representing the abundance and weath of nature. In Kailsh temple of Ellora the carved image of lakshmi is being illustrated seated in a lotus pond, the two elephants are holding the pots in their uplifted trunks. Lakhmi is one of the earliest deities represented by the Indian artist. (Bhartkalyan)The word Lakshmi derived from the term lakshna which means means sign, symbol, lucky mark. Her four arms symbolize the four goals of

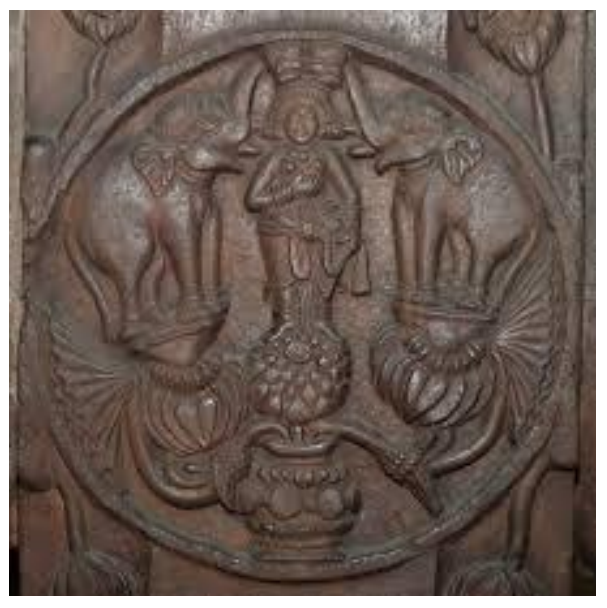
Humanity-Dharma, arth, karma and moksha. The elephants are the symbol of strength and ghat of water symbolizes the fertility for prosperity. ${ }^{4}$

The worship of the goddess is in multitude forms- Ambika is the tender mother, Devi Tara is a source of light. Durga is the goddess of Shakti or Power while Saraswati is the devi of Gyan Kali has the supreme power of destruction. The Indian artist captured the various facets of women in his art. The goddess Durga killing the buffalo demon is portrayed as the sixteen -armed figure

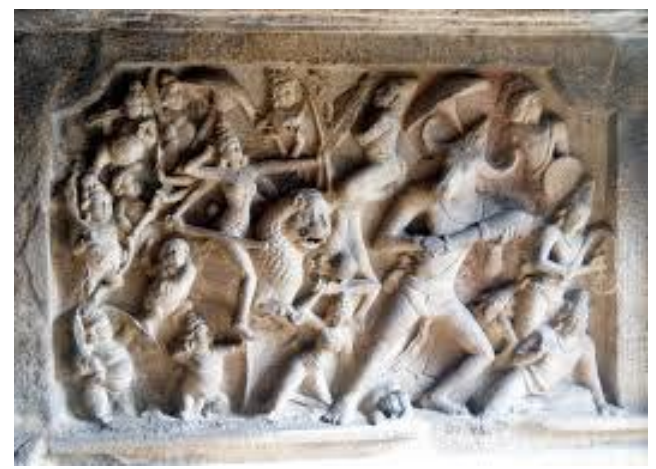
holding in her left hand shield, bow, mirror, noose and bell. In her right hand sword, arrow, chakra, chisel, hammer, thunderbolt, and elephant goad. 12 Century Pal period sculpture is one of the beautiful example of eastern India. ${ }^{5}$

Durga slaying Mahishasur is the prominent theme for Indian artist. In another sculpture of Hoyasal period, the goddess is in eight armed form with the weapons lent by 
the male gods. In Kushan Period the goddess on a lion depicted first time. She appeared as a supreme warrior- goddess in Bramhical culture ${ }^{6}$. In various caves and temples of India this theme is being sculpted. Mammalpuram, Ellora, Virupaksha are some of them. In India the deities are generally portrayed with many arms to emphasize the ability and omnipotence. The prescription of Vishnudharmottar Purana describes about the casting of the image. The depiction of Durga could also be seen in Pahari miniature paintings, in miniature paintings.

The hand modeled and stumpy female figure with bird- faced is also found from Patliputra and Mathura. The ornaments and headdress of the figure are full of floral designs. In Bharut, Sanchi and

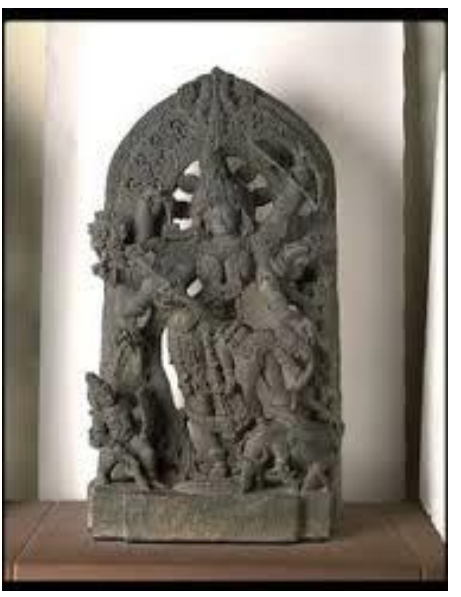
Mathura the figures of Shalbhanjika appear. Yakshis are the nature goddess; the early records of terracotta sculpture are the evidences. Ambica - A jain goddess is the yakshi with the smiling face reflects the maternal compassion. Loin is her vahana. Yoginies are the minor goddess with power and magical powers. The Chousath Yogini temple of $10^{\text {th }}$ Century is famous temple of Khajuraho, Madhya Pradesh. In eastern India Shitala Mata is worshipped she is the goddess of smallpox. ${ }^{8}$

Some of the goddess is the anthromorphic personification of nature. Rivers, sea, morning and evening are named as deities. Goddess River Ganga, Yamuna and Saraswati are engraved at rock cut shrine of Ellora. Ganga and Yamuna are represented in human form with their vahans. These two river goddesses conventionally flank a temple doorway. In many miniature paintings the artist depicted the personification of morning as Usha and the evening as Sandhya. Ragini in feminine form are also installed as a favorite subject of artist of mediaeval period. ${ }^{9}$

"In traditional society art is an integral part of living. Folk art is functional and spontaneous. It also reflects the constancy of

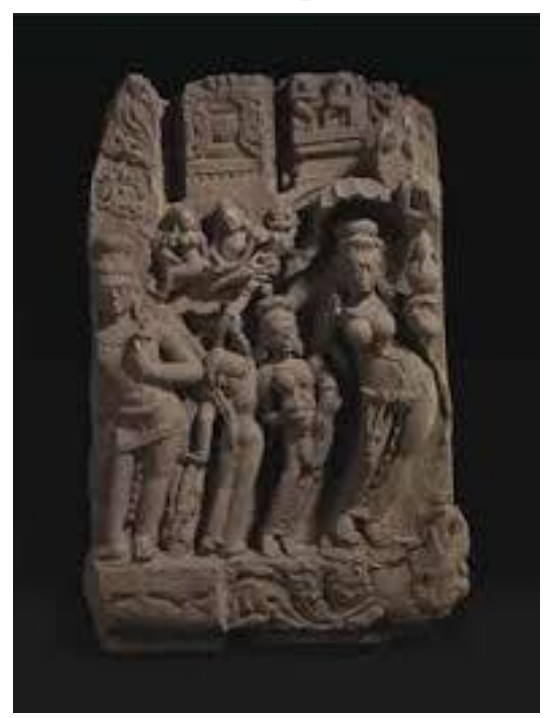
belongingness. In the primitive societies, there is no real distinction fine art and applied art."10

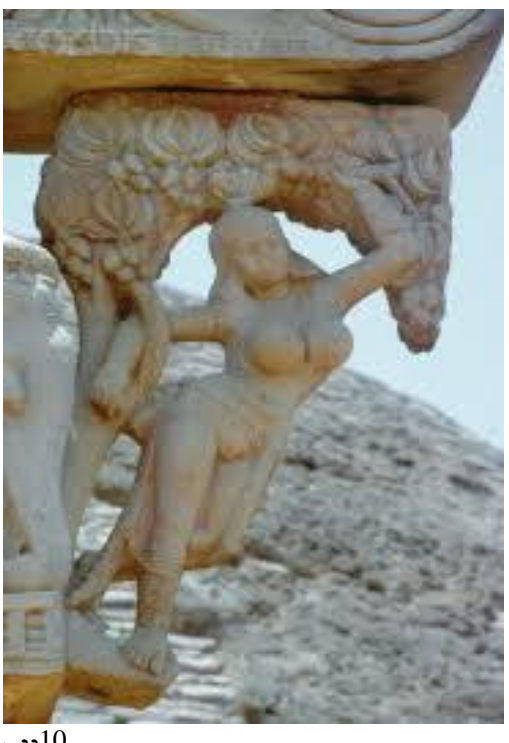

In Folk societies, socialization, education, recreation and communication of new ideas moral values and knowledge are inculcated by the women. They are the main carriers of oral tradition. The essential development in folk society remains due to the folk traditions. Women incorporate the traditions by the songs, tales and art. They are the active bearer of oral tradition in India. ${ }^{11}$

In Indian culture the creator or the originator has been depicted as God or Goddess. As the women originates life or creates the 
life like 'Brahma' nurtures the child like 'Vishnu' and destroys the evils for the protection of child like 'Shiva'. She gets satisfied in less and tries to give more to her family. She even takes the 'roudra roop' to get rid of evils. She plays vital role in entire of her life, the role of daughter, sister, friend, mother and wife. Her vivid role gives her status of "Devi".

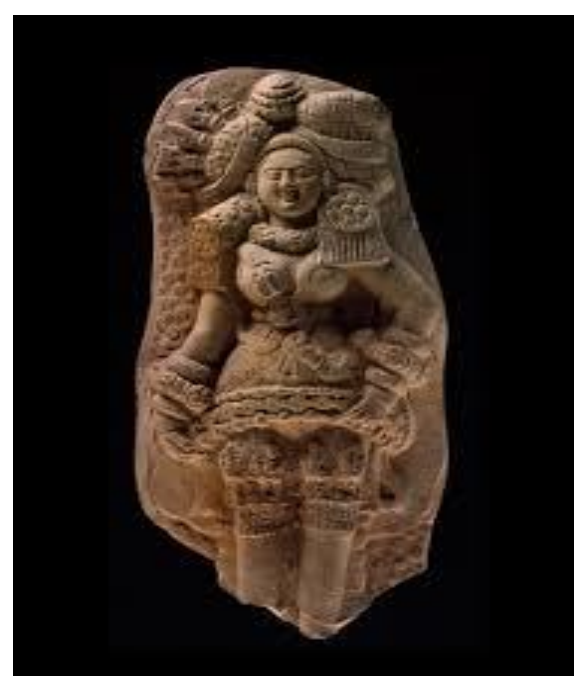

\section{REFERENCES}

[1] Subamanyam K.G., Moving Focus, New Delhi, pg 105

[2] Desai Devangana, Goddesses in clay-the ritual art of the Indian people, India, New Delhi pg 107

[3] Ibid,pg 108

[4] www.google.com; John Guy, Indian Temple Sculpture,Chenni, pg157-169

[5] www.metmusem.org)

[6] John Guy, Indian Temple Sculpture,Chenni, pg157-169

[7] (www.wikipedia.com

[8] John Guy, Ibid

[9] Ibid

[10] Mukhopadhyay Durga Das, Folk Art and Social Communication, New Delhi, pg 50

[11] Ibid

[12] Photographs: courtsy-www.google.com; 